\title{
Severe intellectual disability-epilepsy-anal anomalies-distal phalangeal hypoplasia
}

INSERM

\section{Source}

INSERM. (1999). Orphanet: an online rare disease and orphan drug data base. Severe intellectual disability-epilepsy-anal anomalies-distal phalangeal hypoplasia. ORPHA:94066

Severe intellectual disability-epilepsy-anal anomalies-distal phalangeal hypoplasia is characterised by severe intellectual deficit, epilepsy, hypoplasia of the terminal phalanges, and an anteriorly displaced anus. It has been described in two sisters born to consanguineous parents. The syndrome is transmitted as an autosomal recessive trait and appears to be caused by anomalies in to chromosome regions, one localised to chromosome 1 and the other to chromosome 14. 